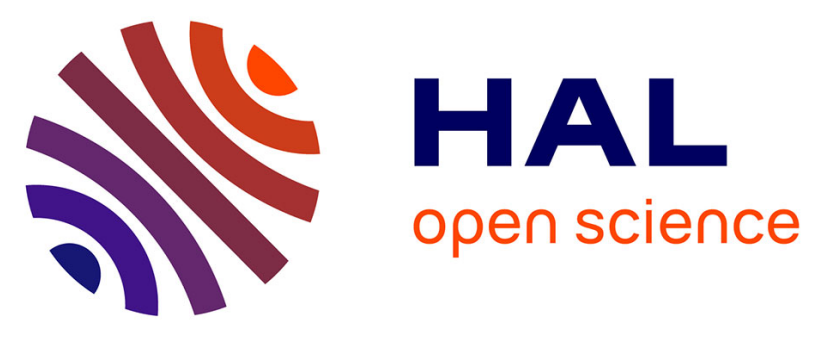

\title{
Pregnane-X-Receptor Mediates The Anti-inflammatory Activities of Rifaximin on Detoxification Pathways in Intestinal Epithelial cells
}

\author{
Andrea Mencarelli, Marco Migliorati, Miriam Barbanti, Sabrina Cipriani, \\ Giuseppe Palladino, Eleonora Distrutti, Barbara Renga, Stefano Fiorucci
}

\section{To cite this version:}

Andrea Mencarelli, Marco Migliorati, Miriam Barbanti, Sabrina Cipriani, Giuseppe Palladino, et al.. Pregnane-X-Receptor Mediates The Anti-inflammatory Activities of Rifaximin on Detoxification Pathways in Intestinal Epithelial cells. Biochemical Pharmacology, 2010, 80 (11), pp.1700. 10.1016/j.bcp.2010.08.022 . hal-00632282

\section{HAL Id: hal-00632282 https://hal.science/hal-00632282}

Submitted on 14 Oct 2011

HAL is a multi-disciplinary open access archive for the deposit and dissemination of scientific research documents, whether they are published or not. The documents may come from teaching and research institutions in France or abroad, or from public or private research centers.
L'archive ouverte pluridisciplinaire HAL, est destinée au dépôt et à la diffusion de documents scientifiques de niveau recherche, publiés ou non, émanant des établissements d'enseignement et de recherche français ou étrangers, des laboratoires publics ou privés. 


\section{Accepted Manuscript}

Title: Pregnane-X-Receptor Mediates The Anti-inflammatory Activities of Rifaximin on Detoxification Pathways in Intestinal Epithelial cells

Authors: Andrea Mencarelli, Marco Migliorati, Miriam

Barbanti, Sabrina Cipriani, Giuseppe Palladino, Eleonora

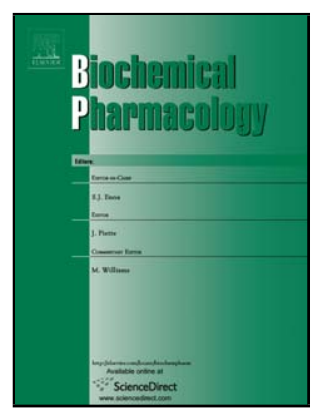

Distrutti, Barbara Renga, Stefano Fiorucci

PII:

S0006-2952(10)00652-0

DOI:

doi:10.1016/j.bcp.2010.08.022

Reference:

BCP 10701

To appear in: $\quad B C P$

Received date: $\quad 15-7-2010$

Revised date: 20-8-2010

Accepted date: $\quad$ 24-8-2010

Please cite this article as: Mencarelli A, Migliorati M, Barbanti M, Cipriani S, Palladino G, Distrutti E, Renga B, Fiorucci S, Pregnane-X-Receptor Mediates The Anti-inflammatory Activities of Rifaximin on Detoxification Pathways in Intestinal Epithelial cells, Biochemical Pharmacology (2010), doi:10.1016/j.bcp.2010.08.022

This is a PDF file of an unedited manuscript that has been accepted for publication. As a service to our customers we are providing this early version of the manuscript. The manuscript will undergo copyediting, typesetting, and review of the resulting proof before it is published in its final form. Please note that during the production process errors may be discovered which could affect the content, and all legal disclaimers that apply to the journal pertain. 
Mencarelli A. et al. Rifaximin regulates intestinal PXR

Ms. No. BCP-D-10-00842-R2

Pregnane-X-Receptor Mediates The Anti-inflammatory Activities of Rifaximin on Detoxification Pathways in Intestinal Epithelial cells

Short Title:

Rifaximin regulates intestinal PXR

Andrea Mencarelli', Marco Migliorati' , Miriam Barbanti3 Sabrina Cipriani', Giuseppe Palladino', Eleonora Distrutti2, Barbara Renga' and Stefano Fioruccil

1 'Dipartimento di Medicina Clinica e Sperimentale, University of Perugia, Facoltà di Medicina e Chirurgia, Via Gerardo Dottori $n^{\circ} 1$ S. Andrea delle Fratte 06132 Perugia - Italy

Azienda Ospedaliera di Perugia, Ospedale Santa Maria della Misericordia, S. Andrea delle Fratte- 06132 Perugia - Italy

${ }^{3}$ Alfa Wassermann SpA,

Via Ragazzi del 99, 40133 Bologna Italy 
Mencarelli A. et al. Rifaximin regulates intestinal PXR

\section{ABSTRACT}

The pregnane-X-receptor (PXR) is master gene overseeing detoxification of wide number of xenobiotics and is critical for maintenance of intestinal integrity. The intestinal expression of genes involved in cellular detoxification is downregulated in patients with inflammatory bowel diseases (IBD). Rifaximin, is a non absorbable antibiotic endowed with a PXR agonistic activity. In the present study we have investigated whether rifaximin activates PXR in primary human colon epithelial cells and human colon biopsies and assessed whether this antibiotic antagonizes the effect of Tumor necrosis factor (TNF)-a on expression of PXR and PXR-related genes. Present results demonstrate that primary colon epithelial cells express PXR and that their exposure to rifaximin induces the expression of genes involved in cellular detoxification. Exposure to TNFa reduces the expression of PXR mRNA as well as expression of its target genes. This inhibitory effect was prevented by that co-treatment with rifaximin. Knocking down the expression of PXR in colon epithelial cells by an anti-PXR siRNA, abrogated the counterregulatory effects exerted by rifaximin on cell exposed to TNFa. Finally, ex vivo exposure of colon biopsies obtained from ulcerative colitis patients to rifaximin increased the expression of genes involved in xenobiotics metabolism. In aggregate, these data illustrate that rifaximin increases the expression of PXR and PXR-regulated genes involved in the metabolism and excretion of xenobiotics and antagonized the effects of TNFa in intertsinal epithelial cells and colon biopsies. These non-antibiotic effects of rifaximin could contribute to the maintenance of the intestinal barrier integrity against xenobiotics and products generated by luminal bacteria.

Keywords: pregnane-X-receptor (PXR), rifaximin, inflammatory bowel diseases (IBD), colon epithelial cells, detoxification system 
Mencarelli A. et al. Rifaximin regulates intestinal PXR

Article Outline

1. Introduction

2. Material and methods

\subsection{Material}

2.2. Cells trea tment

2.3. Cellular modulation of PXR expression with small interfering RNA

2.4. RNA extraction, reverse transcriptase and polymerase chain reaction

2.5. Patients

2.6. Biopsies culture

2.7 Data analysis

3. Results

3.1. Rifaximin modulates the expression of PXR and PXR-regulated genes in intestinal epithelial c ells

3.2. TNFa represses the expression of genes involved in intestinal detoxification

3.3. Rifaximin counter-reacts the effect of TNFa on PXR regulated genes

3.4. Rifaximin regulates the expression of detoxific ation genes in IBD biopsy

4. Discussion

Contributors

References 
Mencarelli A. et al. Rifaximin regulates intestinal PXR

\section{INTRODUCTION}

The pathophysiology of inflammatory bowel disease (IBD), Crohn's disease (CD) and ulcerative colitis (UC), is not yet completely understood [1-5]. In recent years, it has become clear that genetic, immunological, environmental and microbial factors contribute to the aetiology of IBD [1-5]. The epithelial cells, the first line of defence against potentially harmful luminal antigens, are remarkably similar to hepatocytes in their ability to carry out detoxification and bio-transformation of luminal agents of dietary, bacterial or fermentative origin. In the last decade results from animal models as well as studies of IBD patients have shown that colonic epithelial cells might become unable to detoxify toxic metabolites in inflammation [6-11]. Despite the pathogenesis of this epithelial dysfunction is multifactorial and somewhat elusive, the concept of a multilevel alteration of the intestinal detoxification system is recognized as pathogenetic mechanism in IBD $[6,12]$.

The steroid and xenobiotic receptor $(S X R)$, also known as pregnane $X$ receptor (PXR), is a nuclear hormone receptor activated by a diverse array of endogenous hormones, dietary steroids, pharmaceutical agents and xenobiotics [13-15]. PXR has an highly flexible, hydrophobic, ligand binding domain (LBD) which accommodates a wide array of ligands conferring to the receptor a remarkably divergent array of activities across mammalian species. PXR is master gene overseeing detoxification of wide number of xenobiotics and is critical for maintenance of intestinal integrity. Gene expression studies have shown that a down-regulation of xenobiotic metabolism and a dysregulation of PXR transcriptional activity in the gut is strongly associated with the development of IBD 
Mencarelli A. et al. Rifaximin regulates intestinal PXR

[16]. In the dextran sulfate sodium (DSS)-induced colitis, a widely used mouse model for IBD, administration of pregnenolone 16-carbonitrile (PCN), a rodentspecific PXR ligand, attenuates development of colitis and protects against immune dysfunction [17].

A major regulator of inflammation is the transcription factor NF-kB which regulates the expression of a diverse array of genes associated with both innate and adaptive immunity (including many cytokines, chemokines, adhesion proteins and stress response genes) [18]. Recently, it has been shown that the p65 sub-unit of NF-kB interacts with the PXR partner RXRa, and this interaction prevents the binding of PXR to the promoters of target genes [19]. This interaction may account for the inhibition of liver drug metabolism observed in inflammatory states [20]. Conversely, interaction of NF-kB with PXR leads to inhibition of NF-kB activity [20]. Confirming the reciprocal regulation, an increased expression of NF-kB target genes occurs in PXR null mice [20].

ATP binding cassette $(A B C)$ transporters are ATP-dependent membrane proteins predominantly expressed in excretory organs, such as the liver, intestine and kidney [21]. ABC transporters have an important role in tissue defense through the excretion of toxic compounds and their metabolites. The expression of these transporters is tightly regulated, emphasizing their importance in organ protection [21]. Many of these genes are specific targets for PXR. A growing body of data demonstrates that a reciprocal regulation exists between genes that mediate detoxification and inflammation [21]. The role of these genes in regulating the inflammatory signaling is made evident from studies on MDR-1a [22]. Thus, mice deficient in the mdrla gene which encodes for P-glycoprotein, a membrane efflux 
Mencarelli A. et al. Rifaximin regulates intestinal PXR

pump, expressed, among others, by intestinal epithelial cells, develop a spontaneous colitis presumably due to an intestinal epithelial "barrier" defect [22]. Further, MDRla polymorphisms increase the susceptibility to IBD $[23,24]$. These data highlight the fact that the intestinal detoxification system serves a dual role during inflammation, both sending out inflammatory signals as well as protecting the intestinal epithelium. A previous study has shown that rifaximin, a non absorbable antibiotic, is a gut-specific human PXR agonist [25].

In the present study we have investigated whether rifaximin regulates the expression of genes involved in detoxification in human intestinal epithelial cells and colon biopsies from IBD patients. The results of this study support the notion that rifaximin is a ligand for human PXR and that, under rifaximin binding, PXR robustly counter-regulates pro-inflammatory effects of TNFa in colon epithelial cells. 
Mencarelli A. et al. Rifaximin regulates intestinal PXR

\section{MATERIALand METHODS}

\subsection{Material}

Rifaximin, polymorph-a (Alfa Wassermann, Bologna, Italy), batch number 2008.8001312, was dissolved in DMSO at the final concentration of $10 \mathrm{mM}$ and subsequently serial dilutions were made daily in complete F12 medium. The final concentration of DMSO was $0.5 \%$. TNFa was from Invitrogen (Milan, Italy) while all other reagents were from Sigma-Aldrich (Milan, Italy).

\subsection{Cells treatment}

CRL-1790 cells, a human epithelial cell line, (ATCC, Manassas, VA) were used for this study. CRL-1790 cells were grown in F-12 medium enriched with the following components: $0.02 \mathrm{mg} / \mathrm{ml}$ insulin, $0.01 \mathrm{mg} / \mathrm{ml}$ transferrin, $25 \mathrm{nM}$ sodium selenite, 50 $\mathrm{nM}$ hydrocortisone, $1 \mathrm{ng} / \mathrm{ml}$ epidermal growth factor, $0.01 \mathrm{mM}$ ethanolamine, 0.01 $\mathrm{mM}$ phosphorylethanolamine, $100 \mathrm{pM}$ triiodothyronine, $0.5 \%(\mathrm{w} / \mathrm{v})$ bovine serum albumin, $10 \mathrm{mM}$ HEPES, $0.5 \mathrm{mM}$ sodium pyruvate, extra $2 \mathrm{mM}$ L-glutamine (final concentration 4.5 mM). Cell density was maintained at approximately 100,000 cells per milliiter of medium. Cells were then plated in fibronectin- and collagen type I- coated T-25 flasks. The cells were incubated at $37^{\circ} \mathrm{C}$ in $5 \% \mathrm{CO}_{2}$ and $95 \%$ $\mathrm{O}_{2}$ atmosphere and underwent cell passage at $\approx 70 \%$ confluence. Rifaximin and TNFa were added 20 hours before mRNA extraction. In co-treatment experiments rifaximin was added $3 \mathrm{~h}$ before TNFa and cells incubated for $20 \mathrm{~h}$.

\subsection{Cellular modulation of PXR expression by small interfering (si) RNA.}

CRL-1790 cells were suspended to a final concentration of 100,000 cells per milliliter in complete $\mathrm{F} 12$ medium and incubated at $37^{\circ} \mathrm{C}$. The lipid-based 
Mencarelli A. et al. Rifaximin regulates intestinal PXR

transfection agent was used for transfection with PXR siRNA (Origene, Rockville; MD) in accordance to the manufacturer's indication. The cells were incubated for at least $72 \mathrm{~h}$ at $37^{\circ} \mathrm{C}$ in $5 \% \mathrm{CO}_{2}$ after transfection with the anti-PXR siRNA before their use.

\subsection{RNA extraction, reverse transcriptase and polymerase chain reaction}

Quantification of the expression of PXR and genes involved in cellular detoxification was performed by quantitative real-time polymerase chain reaction (RT-PCR) using sense and antisense primers as indicated in Table I. All PCR primers were designed using PRIMER3-OUTPUT software using published sequence data from the NCBI database. Total RNA was isolated from biopsies specimens by TRIzol reagent (Invitrogen srl, Milan, Italy) . One microgram of purified RNA was treated with Dnase I for 15 minutes at room temperature, followed by incubation at $95^{\circ} \mathrm{C}$ for 5 minutes in the presence of $2.5 \mathrm{mmol} / \mathrm{L}$ EDTA. The RNAs were reverse transcribed with Superscript II (Invitrogen srl, Milan, Italy) in a $20 \mu \mathrm{L}$ reaction volume using random primers. For quantitative RT-PCR, 50-100 ng of template were dissolved in a $25 \mu \mathrm{L}$ solution containing $0.2 \mu \mathrm{mol} / \mathrm{L}$ of each primer and $12.5 \mu \mathrm{L}$ of SYBR GreenER qPCR SuperMix for iCycler (Invitrogen srl, Milan, Italy). All reactions were performed in triplicate, and the thermal cycling conditions were as follows: 2 minutes at $50^{\circ} \mathrm{C}, 10$ minutes at $95^{\circ} \mathrm{C}$, followed by 50 cycles of $95^{\circ} \mathrm{C}$ for 15 seconds and $60^{\circ} \mathrm{C}$ for 60 seconds in an iCycler iQ instrument (Bio-Rad, Hercules, CA). The mean value of the replicates for each sample was calculated and expressed as the cycle threshold (CT; cycle number at which each PCR reaction reaches a predetermined fluorescent threshold, set within the linear range of all reactions). 
Mencarelli A. et al. Rifaximin regulates intestinal PXR

The amount of expression of each gene was then calculated as the difference (dCT) between the CT value of the sample for the target gene and the mean CT value of that sample for the endogenous control (GAPDH). Relative expression was calculated as the difference (ddCT) between dCT values of the test control sample for each target gene. The relative expression level was expressed as 2ddCT.

\subsection{Culture of colon biopsies}

Colon biopsies were obtained from 6 patients $(5$ men, mean age $36.3 \pm 4.5$ years) undergoing colonscopy for clinical staging of their disease. All patients were affected by Crohn's disease with a colonic localization. Two of them had also ileal involvement. All subjects were taking active drugs: budesonide (4 patients ) and azathioprine (2 patients). None of the patients had previous surgery. Each patient had an active disease at the macroscopic examination. Samples were taken from inflamed mucosa for histo-pathology analysis, as a part of standard diagnostic assessment. Written consent was obtained from each patient. Biopsies were maintained in cold $\left(4^{\circ} \mathrm{C}\right)$ culture medium, gently washed, three times in RPMI with $3 \%$ of penicillin/streptomycin and cultured on 40 UM mesh filters over a culture dish in 24 well tissue culture plates in complete RPMI medium. They were cultured in the presence or absence of rifaximin (100 $\mu M)$ and incubated at $37^{\circ} \mathrm{C}$ with $5 \% \mathrm{CO} 2$. After $18 \mathrm{~h}$, culture supernatants was removed, while biopsies were processed for RNA extraction. For each subject 4-6 biopsies were obtained. Each colon biopsy was plated individually. Half of the biopsies were used as a control (i.e. not treated with rifaximin) and half were exposed to 
Mencarelli A. et al. Rifaximin regulates intestinal PXR

rifaximin. The effect of rifaximin was compared in each subject with control (i.e. untreated) biopsies.

\subsection{Data analysis}

All values are express as mean \pm SE of " $n$ " experiments. The statistical analysis was done by GraphPad Prism software. The variation between data sets was tested by Student $\dagger$ test for unpaired samples, when we compared two groups. Comparisons of more than 2 groups were made with a 1-way analysis of variance with post hoc Tukey tests. Differences were considered statistically significant if $P$ was $<0.05$. 
Mencarelli A. et al. Rifaximin regulates intestinal PXR

\section{RESULTS}

\subsection{Rifaximin modulates the expression of PXR and PXR-regulated genes in intestinal epithelial cells}

To investigate whether PXR directly regulates the expression of genes involved in the gut detoxification, we have first evaluated the expression of PXR in CRL-1790 cells, a normal human colon epithelial cell line, and compared it to HepG2 cells, an hepatocarcinoma cell line that express high levels of PXR. Results shown in Figure 1, demonstrates that colon epithelial cells express PXR MRNA even if the expression was lower than that of HepG2 cells $\quad(p<0.05$ versus HepG-2 $n=3)$.

We have then examined whether rifaximin (50 $\mu M)$ modulates the expression of genes involved in intestinal detoxification. Cytochrome P450 (CYP) genes encode for phase I monooxygenases which catalyze essential reactions in drug metabolism and synthesis of cholesterol, steroids and other lipids [26]. Exposure of CRL-1790 cells to rifaximin induced a 2-3 fold increase in the expression of CYP3A4, CYP-2C9 and CYP-3A7 mRNAs (Figure $2 \mathrm{~A} ; \mathrm{p}<0.05$ versus control cells; $\mathrm{n}=5$ ). The glutathione S-transferase is a phase II enzyme that functions in the detoxification of electrophilic compounds, including carcinogens, therapeutic drugs, environmental toxins and products of oxidative stress, by conjugation with glutathione [27]. Eight distinct classes of the soluble cytoplasmic mammalian glutathione S-transferases have been identified: alpha, kappa, mu, omega, pi, sigma, theta and zeta [27]. Exposure of CRL-1790 to rifaximin induced GST-A 1 mRNA by $2-3$ folds (Figure 2 B; $p<0.05$ versus control cells; $n=5$ ) but failed to change the expression of GST-M4 and GST-T1 mRNA. 
Mencarelli A. et al. Rifaximin regulates intestinal PXR

The sulfotransferases are phase II enzymes that transfer a sulfonyl moiety from the cofactor 3'-phosphoadenosine-5'-phosphosulfate to hydroxyl, amino, sulfhydryl and $\mathrm{N}$-oxide groups of their substrates [28]. Exposure of CRL-1790 cells to rifaximin induced SULT1A1 mRNA expression and SULT2A1 by 10 fold (Figure 2 B; $p<0.05$ versus control cells; $n=5)$. Further on, rifaximin, was a potent inducer of UGT-1A3 an enzyme involved in glucuronidation pathway that transforms small lipophilic molecules, such as steroids, bilirubin, hormones, and drugs, into water-soluble, excretable metabolites (Figure $2 B ; p<0.05$ versus control cells $n=5$ ).

The superfamily of $A B C$ transporters are phase III proteins that translocate a wide variety of substrates across extra- and intracellular membranes, including metabolic products, lipids and sterols, drugs and environmental agents [21]. Exposure of CRL-1790 cells to rifaximin induced $A B C-B 1, A B C-C 2$ and $A B C-C 3$ by $\approx 2$ folds (Figure $2 \mathrm{C} ; \mathrm{p}<0.05$ versus control cells; $\mathrm{n}=5$ ). Finally, exposure to rifaximin increased PXR $\mathrm{mRNA}$ level by $\approx 2$ folds (Figure $2 \mathrm{C} ; \mathrm{p}<0.05$ versus control cells; $n=5)$.

\subsection{Rifaximin reverts the repression of PXR and PXR-regulated genes caused by} TNFa.

Previous studies have shown that inflammation-driven NF-KB activation antagonizes PXR signalling in liver cells of human and mouse origin causing a robust reduction of CYP genes [21,29]. Because it is unknown whether a similar effect occurs in normal intestinal epithelial cells we investigated whether TNFa regulates the expression of PXR and PXR-regulated genes in intestinal epithelial cells. As shown in Figure 3, exposure of CRL-1790 cells to TNFa $(100 \mathrm{ng} / \mathrm{ml})$ for 20 hours caused a robust reduction in the expression of PXR and all but GPX-1, 
Mencarelli A. et al. Rifaximin regulates intestinal PXR

CES-2 and GST-T1, PXR-regulated genes (panel A-C; P < 0.05 versus control cells; $\mathrm{n}=5$ ). These effects were prevented by treating the cells with rifaximin. Thus, rifaximin effectively enhanced the expression of PXR and PXR-regulated genes in CRL-1790 cells exposed to TNF a ( $<<0.05$ versus TNFa alone).

\subsection{Effects of rifaximin of detoxification genes is abrogated by PXR silencing.}

To explore the mechanistic involvement of PXR in the effect exerted by rifaximin, PXR gene expression was silenced by anti-PXR siRNA. As illustrated in Figure 4, the treatment of CRL-1790 cells with an anti-PXR siRNA almost completely abrogated the expression of PXR ( $p<0.05$ versus non transfected cells). With few exception, we found that exposure of CRL-1790 cells that were made deficient in PXR expression by anti-PXR siRNA completely abrogated the ability of rifaximin to counteract the effects of TNFa (Figure 5 A-C; $P<0.05$ versus TNFa treated cells; $n=3)$.

\subsection{Rifaximin regulates the expression of detoxification genes in human colon}

\section{biopsies.}

To investigate whether the effect of rifaximin is maintained in a complex cellular system, colon biopsies obtained from macroscopically inflamed areas of colons of patients with ulcerative colitis were cultured ex-vivo with rifaximin. Results from these experiments (Figure 6 A; $\mathrm{p}<0.05$ versus untreated biopsies; $n=16$ and $n=17$, respectively) demonstrated that PXR is expressed in colon human biopsies and that rifaximin $(100 \mu \mathrm{M})$ effectively increased the expression of CYP3A7 and CYP-2C9 by 2 folds, sulfotransferases and glucuronosyltransferases, with 
Mencarelli A. et al. Rifaximin regulates intestinal PXR

the exception of SUL-1A3, by 2 folds (Figure 6 B; $p<0.05$ versus untreated biopsies; $n=10$ ), and $A B C-B 1$ and $A B C-C 3$ by $2-3$ folds (Figure $6 C ; p<0.05$ versus untreated biopsies; $n=12-15)$. 
Mencarelli A. et al. Rifaximin regulates intestinal PXR

\section{DISCUSSION}

A single layer of intestinal epithelial cells make up the barrier between the host and the luminal content of the intestine. The cells of the mucosal immune system are protected against the luminal antigen load by this layer of epithelial cells. Disturbance of the integrity of the epithelial cell barrier contributes to the development of mucosal inflammation exposing the intestinal immune system to bacteria products and toxins [12]. Protective mechanisms that maintain intestinal barrier function include detoxification and biotransformation of luminal substances. The ability of intestinal epithelial cells to handle luminal antigens and xenobiotics is dependent on the activity of a large group of genes. Phase I reactions are largely dependent on the activity of proteins encoded by the cytochrome P450 (CYP) superfamily [7,8]. The phase I metabolites can either be eliminated directly from the body or could subject to further biotransformation by phase II enzymes. The primary organ of drug metabolism is the liver, but the intestine is involved, as reflected by the expression of CYP enzymes in this tissue $[9,10]$. In addition, transporters, sometimes called phase III proteins, can determine foreign compound bioavailability, distribution, and elimination. The genes involved in drug metabolism provide an adaptive response to environmental challenge, and as a consequence, their expression is tightly regulated by foreign compounds themselves [11]. The $A B C B 1$ (MDR1) and additional $A B C$ transporters with a high expression in the gut such as $A B C C l-3$ (MRPI-3) are critically involved in the maintenance of the intestinal barrier by excluding drugs, nutrients, or bacterial compounds back into the gut lumen [22, 30-32]. Furthermore, the association of MDR1 gene polymorphisms with susceptibility for IBD $[23,24]$ implies that genetic 
Mencarelli A. et al. Rifaximin regulates intestinal PXR

variations or dysregulation of $A B C$ transporters contribute to the development of IBD. Moreover it has been found that a down-regulation of detoxification genes, specifically sulfotransferases and glucuronosyltransferase and ABC transporters, occurs in the colon of patients with IBD [16]. This dysregulation is accompanied by a nearly complete loss of the transcriptional regulator PXR. This finding might have a pathogenetic relevance for IBD either because PXR is essential for regulation of detoxification pathways and for its anti-inflammatory activity and NF-KB modulating activity $[16,19]$.

Rifaximin is a poorly absorbed oral antimicrobial agent that is concentrated in the gastrointestinal tract [33-35]. Rifaximin has a broad-spectrum of activity against gram-positive and gram-negative aerobic and anaerobic enteric bacteria [36-38]. In addition to its anti- bacterial activity rifaximin exerts anti-inflammatory and immunomodulatory effects [38] in human tissues and in vivo. Despite the compound is poorly absorbed there is evidence that it penetrates intestinal cells. This was, among other, shown recently by the fact that administration of rifaximin to mice harbouring a human PXR gene results in induction of PXR and PXR regulated genes in the intestine [25].

In the present study we have demonstrated that exposure of primary epithelial colon cells to rifaximin modulates the expression of genes involved in cellular detoxification and that this effect requires PXR. Thus, exposure to rifaximin effectively increased the expression of CYP3-A4, CYP-3A7, CYP-2C9, GSTA1, SULT-1A1, SULT-1A3, SULT-2A1, UGT-1A3 and phase III transporters in naïve cells. In addition, rifaximin effectively counter-regulated the inhibitory effects caused by exposure of human epithelial cells to TNFa. Indeed, while TNFa reduced the 
Mencarelli A. et al. Rifaximin regulates intestinal PXR

expression of PXR and its target genes, with the exception of GPX-1 and CES-2 and GST-T, this effect was antagonized by incubating the cells with rifaximin. The effects exerted by rifaximin on the expression of genes involved in intestinal epithelial detoxification was mediated by PXR. This contention is supported by the following observations. First, all genes that are modified by exposure to rifaximin were modulated by PXR and specific PXR binding motifs, either as direct repeat (DR) or everted repeat (ER), ER6, DR4 and DR3 [21], were reported to be expressed in their promoter regions (Table 1). In addition, results from experiments where the expression of PXR was knocked down by specific anti-PXR siRNA, demonstrate that the regulatory effect of rifaximin was lost in cells lacking the nuclear receptor. More specifically we have found that PXR is required by rifaximin in order to modulate the expression of CYP-3A4, CYP-3A7, GST-A1, SULT1A1, SULT-1A3, SULT-2A1, UGT-1A3 and ABC-B1 (see Table 2).

Beside its effect on human cultured epithelial cells, rifaximin modulates detoxification pathways in colon biopsies obtained from IBD patients. In these ex vivo studies we found that exposure to rifaximin effectively increased the expression of CYP-3A7, CYP-2C9, SULT-1A1, SULT-2A1, UGT-1A3, ABC-B1 and ABCC3 in colon biopsies obtained from a macroscopically inflamed tissue. This observation might have a clinical readout. Indeed, since TNFa negatively regulates the expression of genes involved in intestinal detoxification in vitro and the activities of detoxification pathways is highly compromised in IBD patients, as a part of the intestinal inflammatory syndrome, it appears that counter-regulation of inhibitory activities of TNFa on detoxification genes might contribute to the beneficial effects of rifaximin in IBDs. 
Mencarelli A. et al. Rifaximin regulates intestinal PXR

In contrast to normal intestinal epithelial cells rifaximin was unable to induce PXR expression in CRL1790 cells exposed to TNFa (Figure 3 panel C). Similar results were obtained in colon biopsies (Figure 6). Thus it appears that during inflammation rifaximin induces PXR activity but not its expression. Support to this notion comes from the observation that the mutual regulation of NF-kB and PXR did not involve modulation of their expression but is rather mediated by changes in transcriptional activity $[20,29]$.

In conclusions, present results demonstrate that rifaximin a non absorbable antibiotic has a direct effects on intestinal epithelial cells. Rifaximin increases the expression of PXR in intestinal epithelial cells and modulates the expression of genes involved in intestinal detoxification in a PXR-dependent manner $[39,40]$. A PXR-mediated effects is required by rifaximin to counter-regulate the inhibitory effects of TNFa on genes involved metabolism and excretion of xenobiotics in intestinal cells. Collectively, these data establish that, in addition to its antibiotic activities, rifaximin regulates the expression of genes essential to the intestinal detoxification of xenobiotic and luminal antigens in a PXR-dependent manner. 
Mencarelli A. et al. Rifaximin regulates intestinal PXR

\section{CONIRIBUTORS}

AM participated in the design of the study, data analysis and writing of the manuscript. MM contributed RT-PCR data. MB contributed to interpretation of data and drafting of the manuscript. SC contributed to cell culture experiments. GP contributed to RT-PCR data. ED and BR contributed to data analysis and manuscript writing. SF designed the study, contributed to interpretation of data and wrote the manuscript. All authors have read and approved the final version of manuscript. 
Mencarelli A. et al. Rifaximin regulates intestinal PXR

\section{REFERENCE}

1. Scholmerich J. New developments in aetiological mechanisms of inflammatory bowel disease. Eur J Gastroenterol Hepatol 2003; 15: 585-6

2. Rogler G. Update in inflammatory bowel disease pathogenesis. Curr Opin Gastroenterol 2004; 20: $311-7$

3. Schmidt C, Stallmach A. Etiology and pathogenesis of inflammatory bowel disease. Minerva Gastroenterol Dietol 2005; 51: 127-145

4. Bamias G, Nyce MR, De La Rue SA, Cominelli F. New concepts in the pathophysiology of inflammatory bowel disease. Ann Intern Med 2005; 143: 895-904

5. Ahmed FE. Role of genes, the environment and their interactions in the etiology of inflammatory bowel diseases. Expert Rev Mol Diagn 2006; 6: 345363

6. Langmann T, Schmitz $G$. Loss of detoxification in inflammatory bowel disease. Nat Clin Pract Gastroenterol Hepatol 2006; 3: 358-9

7. Wolf CR, Seilman S, Oesch F, Mayer RT, Burke MD. Multiple forms of cytochrome P-450 related to forms induced marginally by phenobarbital. Differences in structure and in the metabolism of alkoxyresorufins. Biochem. J. 1986; 240:27-33. 
Mencarelli A. et al. Rifaximin regulates intestinal PXR

8. Gonzalez FJ, Gelboin HV. Role of human cytochromes P450 in the metabolic activation of chemical carcinogens and toxins. Drug Metab. Rev. 1994; 26:165-183.

9. Bergheim I, Bode C, Parlesak A. Distribution of cytochrome P450 2C, 2El, 3A4, and 3A5 in human colon mucosa. BMC Clin. Pharmacol. 2005 5:4.

10.Sarikaya D, Bilgen C, Kamataki T, Topcu Z. Comparative cytochrome P450 $1 A 1,-2 A 6,-2 B 6,-2 C,-2 D 6,-2 E 1,-3 A 5$ and $-4 B 1$ expressions in human larynx tissue analysed at mRNA level. Biopharm. Drug Dispos. 2006; 27:353-9.

11.Xie W, Uppal H, Saini SP, MU Y, Little JM, Radominska-Pandya A, Zemaitis MA. Orphan nuclear receptor-mediated xenobiotic regulation in drug metabolism. Drug Discov. Today. 2004; 9:442-9.

12. Roediger W E, Babidge W. Human colonocyte detoxification. Gut 1997; 41: $731-4$

13. Kliewer SA, Goodwin B, Willson TM. The nuclear pregnane X receptor: a key regulator of xenobiotic metabolism. Endocr Rev 2002; 23: 687-702.

14. Rosenfeld JM, Vargas R, Jr. Xie W, Evans RM. Genetic profiling defines the xenobiotic gene network controlled by the nuclear receptor pregnane $\mathrm{X}$ receptor. Mol Endocrinol 2003; 17:1268-1282.

15.Sonoda J, Chong LW, Downes M, Barish GD, Coulter S, Liddle C, et al. Pregnane $\mathrm{X}$ receptor prevents hepatorenal toxicity from cholesterol metabolites. Proc Natl Acad Sci U S A 2005; 102: 2198-2203.

16. Langmann T, Moehle C, Maverer R, Scharl M, Liebisch G, Zahn A, et al. Loss of detoxification in inflammatory bowel disease: dysregulation of pregnane X receptor target genes. Gastroenterology 2004; 127:26-40. 
Mencarelli A. et al. Rifaximin regulates intestinal PXR

17.Shah YM, Ma X, Morimura K, Kim I, Gonzalez FJ. Pregnane X receptor activation ameliorates DSS-induced inflammatory bowel disease via inhibition of NF-kB target gene expression. Am J Physiol 2007; 292:G1114G1122.

18. Ghosh S, Karin M. Missing pieces in the NF-kappaB puzzle, Cell 2002; 109: S81S96.

19. Gu X, Ke S, Liu D, Sheng T, Thomas PE, Rabson AB, et al. Role of NF-kappaB in regulation of PXR-mediated gene expression, a mechanism for the suppression of cytochrome P-4503A4 by pro-inflammatory agents, J. Biol. Chem. 2006; 281: 17882-9.

20. Morgan ET. Regulation of cytochromes P450 during inflammation and infection. Drug Metab. Rev. 1997; 29: 1129-88.

21. Klaassen CD, Aleksunes LM. Xenobiotic, bile acid, and cholesterol transporters: function and regulation. Pharmacol Rev. 2010;62:1-96

22. Panwala CM, Jones JC, Viney JL. A novel model of inflammatory bowel disease: mice deficient for the multiple drug resistance gene, mdrla, spontaneously develop colitis. J Immunol 1998, 161: 5733-44

23. Schwab M, Schaeffeler E, Marx C, Fromm MF, Kaskas B, Metzler J, et al. Association between the C3435T MDRl gene polymorphism and susceptibility for ulcerative colitis. Gastroenterology 2003; 124: 26-33.

24. Brant SR, Panhuysen Cl, Nicolae D, Reddy DM, Bonen DK, Karaliukas R. et al. MDR1 Ala893 polymorphism is associated with inflammatory bowel disease. Am J Hum Genet 2003; 73: 1282-1292 
Mencarelli A. et al. Rifaximin regulates intestinal PXR

25. Ma X, Shah YM, Guo GL, Wang T, Krausz KW, Idle JR, Gonzalez FJ. Rifaximin is a gut-specific human pregnane $X$ receptor activator. J Pharmacol Exp Ther. 2007; 322: $391-8$

26. Danielson P. The cytochrome P450 superfamily: biochemistry, evolution and drug metabolism in humans. Curr Drug Metab 2002; 3: 561-97

27. Bogaards JJ, van Ommen B, van Bladeren PJ. Purification and characterization of eight glutathione S-transferase isoenzymes of hamster. Comparison of subunit composition of enzymes from liver, kidney, testis, pancreas and trachea. Biochem. J. 1992; 286:383-8

28. Lilla C, Risch A, Verla-Tebit E, Hoffmeister M, Brenner H, Chang-Claude J. SULTIAl genotype and susceptibility to colorectal cancer. Int J Cancer. 2007; 120: 201-6.

29. Gu X, Ke S, Liu D, Sheng T, Thomas PE, Rabson AB, et al. Role of NF-kappaB in regulation of PXR-mediated gene expression, a mechanism for the suppression of cytochrome P-4503A4 by pro-inflammatory agents, J. Biol. Chem. 2006; 281: 17882-9.

30. Ho GT, Moodie FM, Satsangi J. Multidrug resistance 1 gene (P-glycoprotein 170): an important determinant in gastrointestinal disease?. Gut 2003; 52: $759-66$

31.Langmann T, Maverer R, Zahn A, Moehle C, Probst M, Stremmel W, Schmitz G. Real-time reverse transcription-PCR expression profiling of the complete human ATP-binding cassette transporter superfamily in various tissues. Clin Chem 2003; 49: 230-8 
Mencarelli A. et al. Rifaximin regulates intestinal PXR

32. Panwala CM, Jones JC, Viney JL. A novel model of inflammatory bowel disease: mice deficient for the multiple drug resistance gene, mdrla, spontaneously develop colitis. J Immunol 1998; 161: 5733-44.

33. Gerard L, Garey KW, DuPont HL. Rifaximin: a nonabsorbable rifamycin antibiotic for use in nonsystemic gastrointestinal infections. Expert Rev Anti Infect Ther 2005; 3:201-11.

34. Jiang ZD, DuPont HL. Rifaximin: in vitro and in vivo antibacterial activity. Chemotherapy 2005; 51: 67-72.

35. Debbia EA, Maioli E, Roveta S, Marchese A. Effects of rifaximin on bacterial virulence mechanisms at supra- and sub-inhibitory concentrations. J Chemother 2008; 20:186-94.

36. Fiorucci S, Distrutti E, Mencarelli A, Barbanti M, Palazzini E, Morelli A. Inhibition of intestinal bacterial translocation with rifaximin modulates lamina propria monocytic cells reactivity and protects against inflammation in a rodent model of colitis. Digestion. 2002; 66:246-56.

37. Bass NM, Mullen KD, Sanyal A, Poordad F, Neff G, Leevy CB, et al. Rifaximin Treatment in Hepatic Encephalopathy. N Engl J Med 2010; 362: 1071-81

38.Scarpignato C, Pelosini I. Rifaximin, a poorly absorbed antibiotic: pharmacology and clinical potential. Chemotherapy 2005; 51:36-66

39. Arrese M, Karpen SJ. Nuclear receptors, inflammation, and liver disease: insights for cholestatic and fatty liver diseases. Clin Pharmacol Ther. 2010; 87:473-8. 
Mencarelli A. et al. Rifaximin regulates intestinal PXR

40. McKay LI, Cidlowski JA. Molecular control of immune/inflammatory responses: interactions between nuclear factor-kappa B and steroid receptor-signaling pathways. Endocr. Rev.1999; 20: 435-459. 
Mencarelli A. et al. Rifaximin regulates intestinal PXR

Figure Legends

Figure 1. The nuclear receptor PXR is expressed by nomal human colon epithelial cells. $(A, B)$ qualitative and quantitative PCR showing expression of PXR mRNA by normal human colon cells (CRL1790). Hep-G2 cells, an human hepatic carcinoma cell line, was used as a positive control. ( ${ }^{*} p<0.05$ versus HepG2; $n=3$ ).

\section{Figure 2. Rifaximin modulates the expression of genes involved in xenobiotic detoxification in nomal colon epithelial cells.}

Exposure of human colon epithelial cells to rifaximin $(50 \mu \mathrm{M})$ for 20 hours, increases the expression of genes involved in cellular detoxification. Panel A) shows the expression of phase I genes, (Panel B) phase II genes and (Panel C) phase III genes and PXR mRNA. ( ${ }^{*} p<0.05$ versus untreated cells; $\left.n=5\right)$.

Figure 3. TNFa is a negative modulator of genes involved in xenobiotic detoxification in nomal colon epithelial cells.

Exposure to TNFa $(100 \mathrm{ng} / \mathrm{ml})$ decreases the expression of genes involved in cellular detoxification. Pre-treating CRL1790 cells with rifaximin (50 $\mu \mathrm{M})$ antagonized the effects of TNFa. (Panel A) shows the expression of phase I genes, (Panel B) phase II genes, and (Panel C) phase III genes and PXR mRNA. ${ }^{*} \mathrm{p}<0.05$ versus naive cells and \#p $<0.05$ versus TNFa treated cells; $N=3-5$ )

Figure 4. PXR silencing in nomal colon epithelial cells. 
Mencarelli A. et al. Rifaximin regulates intestinal PXR

Assessment of PXR mRNA expression in cells transfected with anti-PXR siRNA. A) qualitative RT-PCR of PXR mRNA; B) quantitative RT-PCR of PXR mRNA in CRL1790 cells.

Figure 5. Counter-regulation of TNFa activities exerted by nifaximin in nomal intestinal epithelial cells requires PXR.

Human colon epithelial cells (CRL1790 cells) transfected with anti-PXR siRNAs were treated with TNFa $(100 \mathrm{ng} / \mathrm{ml})$ alone or in combination with rifaximin (50 $\mathrm{MM})$. Expression of tested genes was compared with their expression in wild type cells treated with TNFa alone. Panel A) expression of phase I genes; Panel B) phase II genes and Panel C) phase III gene and PXR. (\#p < 0.05 versus wild type TNFa treated cells; $n=3$ )

Figure 6: Rifaximin modulates the expression of genes involved in epithelial detoxification in colon biopsies from IBD patients.

Rifaximin $(100 \mu \mathrm{M})$ increased the expression of genes involved in cellular detoxification in ex vivo experiments. Results of culturing colon biopsies obtained from areas of macroscopically inflamed colon of IBD patients with rifaximin are shown. Panel A) expression of phase I genes; Panel B) phase II genes and Panel C) phase III genes and PXR mRNA. ( ${ }^{*} \mathrm{p}<0.05$ versus untreated biopsies. $\left.\mathrm{n}=10-15\right)$. 
Mencarelli A. et al. Rifaximin regulates intestinal PXR 
Mencarelli A. et al. Rifaximin regulates intestinal PXR

Table I: List of primers used for real-time PCR and the PXR responsive elements (PXR-RE) expressed in the promoter of each gene.

\begin{tabular}{|l|c|c|}
\hline $\begin{array}{c}\text { Gene and relative } \\
\text { PXR-RE }\end{array}$ & Primer sense & Primer antisense \\
\hline Phase I & & \\
\hline CYP-3A4 (ER6) & CAAGACCCCTTTGTGGAAAA & CGAGGCGACTTTCTTTCATC \\
\hline CYP-2C9 (DR4) & AATTTGGGATGGGGAAGAG & AAGTGGGATCACAGGGTGAG \\
\hline CYP-3A7 (ER6) & CAAGACCCCTTTGGGAAAA & TGTCTCTTGAGGCGACCTT \\
\hline CES-2 (DR3) & CTGGGGAGTCTTGTCCATGT & CCCTCACACCACTCCAAGAT \\
\hline GXP-1 (DR3) & CCAAGCTCACCTGGTCT & TCGATGTCAATGGTCTGGAA \\
\hline Phase II & ATCGCTACTTCCCTGCCTTT & CTTCTTCACTGTGGGCAGGT \\
\hline GST-A1 (DR3) & TTTCCTCGCCTATGATGTCC & CAGACAGCCACCCTTGTGTA \\
\hline GST-M4 (ER6) & GCCAAGAAGAACGACATTCC & CCTTATATTTGCGCGTCAGG \\
\hline GST-T1 (DR3) & CATGGTCGGAGAAGTGTCCT & GAATCTCCCTTTTCGGGTTC \\
\hline SULT-1A1 (DR3) & CACGTCGTTCAAGGAGATGA & GCCATCTTCTCCGCATAGTC \\
\hline SULT-1A3 (DR3) & GATCCAATCTGTGCCCATCT & TAAATCACCTTGGCCTTGGA \\
\hline SULT-2A1 (DR4) & TAAGTGGCTACCCCAAAACG & GCTTTGCATTGTCCATCTGA \\
\hline UGT-1A3 (DR3) & \\
\hline Phase III & CTTATGCTCTGGCCTCTGG & GGAGATGCCTGTCCAACACT \\
\hline ABC-B1 (DR4) & AGAGCTGGCCCTTGTACTCA & AGGGACAGGAACCAGGAGTT \\
\hline ABC-C2 (DR3) & TTCTGGGACTCCAACCTGTC & ACACCCAGGACCATCTTGAG \\
\hline ABC-C3 (DR4) & CTGGAGGTGAGACCCAAAGA & CACATACACGGCAGATTTGG \\
\hline PXR &
\end{tabular}

$\mathrm{ER}=$ Everted repeat. $\mathrm{DR}=$ Direct repeat 
Table 2. Summary of the effects exerted by nifaximin and TNF $\alpha$ on the expression of detoxification genes.

Primary human colon epithelial cells were exposed to TNFa alone or to a combination of TNFa plus rifaximin $(50 \mu \mathrm{M})$ and the expression of genes encoding for enzymes involved in detoxification assessed by RT-PCR. The list of genes that were induced by rifaximin, in a PXR-dependent manner is shown in green and includes: phase I: cytochrome P450 family CYP3-A4 and CYP-3A7; phase II: GSTA1, Sulfotransferases family SULT-1A1, SULT-1A3, SULT-2A1 and UDP glucuronosyltransferase UGT-1A3.; and phase III: ATP-binding cassette ABC-B1. Genes whose expression was induced by exposure of either primary epithelial cells and human colon biopsies to rifaximin is shown in orange.

\begin{tabular}{|c|c|c|c|c|}
\hline Gene & $\begin{array}{l}\text { Effect of } \\
\text { nifaximin in } \\
\text { naïve cells }\end{array}$ & $\begin{array}{l}\text { Effect of TNFa } \\
\text { in naïve cells }\end{array}$ & $\begin{array}{c}\text { Effects of Rifaximin } \\
\text { mediated by PXR } \\
\text { (abrogated by } \\
\text { anti-PXR siRNA) }\end{array}$ & $\begin{array}{l}\text { Effect of rifaximin } \\
\text { in IBD biopsies }\end{array}$ \\
\hline Phase I & & 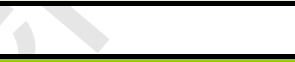 & & \\
\hline CYP-3A4 & Increased & Decreased & YES & No effect \\
\hline CYP-2C9 & Increased & Decreased & $\mathrm{NO}$ & Increased \\
\hline CYP-3A7 & Increased & Decreased & YES & Increased \\
\hline CES-2 & No effect & No effect & $\mathrm{NO}$ & No effect \\
\hline GXP-1 & No effect & No effect & NO & No effect \\
\hline \multicolumn{5}{|l|}{ Phase II } \\
\hline GST-Al & Increased & Decreased & YES & No effect \\
\hline GST-M4 & No effect & Decreased & $\mathrm{NO}$ & No effect \\
\hline GST-TI & No effect & No effect & YES & No effect \\
\hline SULT-1A1 & Increased & Decreased & YES & Increased \\
\hline SULT-1A3 & Increased & Decreased & YES & No effect \\
\hline SULT-2AI & Increased & Decreased & YES & Increased \\
\hline UGT-1A3 & Increased & Decreased & YES & Increased \\
\hline \multicolumn{5}{|l|}{ Phase III } \\
\hline$A B C-B 1$ & Increased & Decreased & YES & Increased \\
\hline
\end{tabular}


Mencarelli A. et al. Rifaximin regulates intestinal PXR

\begin{tabular}{|l|l|l|l|l|}
\hline$A B C-C 2$ & Increased & Decreased & YES & No effect \\
\hline ABC-C3 & Increased & Decreased & NO & Increased \\
\hline & & & & \\
\hline PXR & Increased & Decreased & & No effect \\
\hline
\end{tabular}


Mencarelli A. et al. Rifaximin regulates intestinal PXR

\section{Figure Legends}

Figure 1. The nuclear receptor PXR is expressed by normal human colon epithelial cells. (A,B) qualitative and quantitative PCR showing expression of PXR mRNA by normal human colon cells (CRL1790). Hep-G2 cells, an human hepatic carcinoma cell line, was used as a positive control. (*p $<0.05$ versus HepG2; $n=3$ ).

Figure 2. Rifaximin modulates the expression of genes involved in xenobiotic detoxification in normal colon epithelial cells.

Exposure of human colon epithelial cells to rifaximin $(50 \mu \mathrm{M})$ for 20 hours, increases the expression of genes involved in cellular detoxification. Panel A) shows the expression of phase I genes, (Panel B) phase II genes and (Panel C) phase III genes and PXR mRNA. $(* \mathrm{p}<0.05$ versus untreated cells; $\mathrm{n}=5$ ).

Figure 3. TNFa is a negative modulator of genes involved in xenobiotic detoxification in normal colon epithelial cells.

Exposure to TNFa $(100 \mathrm{ng} / \mathrm{ml})$ decreases the expression of genes involved in cellular detoxification. Pre-treating CRL1790 cells with rifaximin (50 $\mu \mathrm{M})$ antagonized the 
Mencarelli A. et al. Rifaximin regulates intestinal PXR

\author{
effects of TNFa. (Panel A) shows the expression of phase I genes, (Panel B) phase II \\ genes, and (Panel C) phase III genes and PXR mRNA. (*p $<0.05$ versus naive cells and \\ \# $\mathrm{p}<0.05$ versus TNFa treated cells; $\mathrm{N}=3-5$ )
}

Figure 4. PXR silencing in normal colon epithelial cells.

Assessment of PXR mRNA expression in cells transfected with anti-PXR siRNA. A) qualitative RT-PCR of PXR mRNA; B) quantitative RT-PCR of PXR mRNA in CRL1790 cells.

Figure 5. Counter-regulation of TNFa activities exerted by rifaximin in normal intestinal epithelial cells requires PXR.

Human colon epithelial cells (CRL1790 cells) transfected with anti-PXR siRNAs were treated with TNFa $(100 \mathrm{ng} / \mathrm{ml})$ alone or in combination with rifaximin $(50 \mu \mathrm{M})$. Expression of tested genes was compared with their expression in wild type cells treated with TNFa alone. Panel A) expression of phase I genes; Panel B) phase II genes and Panel C) phase III gene and PXR. (\#p < 0.05 versus wild type TNFa treated cells; $n=3$ ) 
Mencarelli A. et al. Rifaximin regulates intestinal PXR

Figure 6: Rifaximin modulates the expression of genes involved in epithelial detoxification in colon biopsies from IBD patients.

Rifaximin $(100 \mu \mathrm{M}) \quad$ increased the expression of genes involved in cellular detoxification in ex vivo experiments. Results of culturing colon biopsies obtained from areas of macroscopically inflamed colon of IBD patients with rifaximin are shown. Panel A) expression of phase I genes; Panel B) phase II genes and Panel C) phase III genes and PXR mRNA. (*p $<0.05$ versus untreated biopsies. $\mathrm{n}=10-15)$. 
Table I: List of primers used for real-time PCR and the PXR responsive elements (PXR-

$\mathrm{RE}$ ) expressed in the promoter of each gene.

\begin{tabular}{|l|l|c|}
\hline \multicolumn{1}{|c|}{$\begin{array}{c}\text { Gene and relative } \\
\text { PXR -RE }\end{array}$} & Primer sense & Primer antisense \\
\hline Phase I & & \\
\hline CYP-3A4 (ER6) & CAAGACCCCTTTGTGGAAAA & CGAGGCGACTTTCTTTCATC \\
\hline CYP-2C9 (DR4) & AATTTTGGGATGGGGAAGAG & AAGTGGGATCACAGGGTGAG \\
\hline CYP-3A7 (ER6) & CAAGACCCCTTTGTGGAAAA & TGTCTCTTTGAGGCGACCTT \\
\hline CES-2 (DR3) & CTGGGGAGTCTTGTCCATGT & CCCTCACACCACTCCAAGAT \\
\hline GXP-1 (DR3) & CCAAGCTCACCTGGTCT & TCGATGTCAATGGTCTGGAA \\
\hline Phase II & & \\
\hline GST-A1 (DR3) & ATCGCTACTTCCCTGCCTTT & CTTCTTCACTGTGGGCAGGT \\
\hline GST-M4 (ER6) & TTTCCTCGCCTATGATGTCC & CAGACAGCCACCCTTGTGTA \\
\hline GST-T1 (DR3) & GCCAAGAAGAACGACATTCC & CCTTATATTTGCGCGTCAGG \\
\hline SULT-1A1 (DR3) & CATGGTCGGAGAAGTGTCCT & GAATCTCCCTTTTCGGGTTC \\
\hline SULT-1A3 (DR3) & CACGTCGTTCAAGGAGATGA & GCCATCTTCTCCGCATAGTC \\
\hline SULT-2A1 (DR4) & GATCCAATCTGTGCCCATCT & TAAATCACCTTGGCCTTGGA \\
\hline UGT-1A3 (DR3) & TAAGTGGCTACCCCAAAACG & GCTTTGCATTGTCCATCTGA \\
\hline Phase III & & \\
\hline ABC-B1 (DR4) & CTTATGCTCTGGCCTTCTGG & GGAGATGCCTGTCCAACACT \\
\hline ABC-C2 (DR3) & AGAGCTGGCCCTTGTACTCA & AGGGACAGGAACCAGGAGTT \\
\hline ABC-C3 (DR4) & TTCTGGGACTCCAACCTGTC & ACACCCAGGACCATCTTGAG \\
\hline PXR & CAGGAGGTGAGACCCAAAGA & CACATACACGGCAGATTTGG \\
\hline
\end{tabular}

$\mathrm{ER}=$ Everted repeat. $\mathrm{DR}=$ Direct repeat 
Mencarelli A. et al. Rifaximin regulates intestinal PXR

Table 2. Summary of the effects exerted by rifaximin and TNF $\alpha$ on the expression of detoxification genes.

Primary human colon epithelial cells were exposed to TNFa alone or to a combination of TNFa plus rifaximin $(50 \mu \mathrm{M})$ and the expression of genes encoding for enzymes involved in detoxification assessed by RT-PCR. The list of genes that were induced by rifaximin, in a PXR-dependent manner is shown in green and includes: phase I: cytochrome P450 family CYP3-A4 and CYP-3A7; phase II: GST-A1, Sulfotransferases family SULT-1A1, SULT-1A3, SULT-2A1 and UDP glucuronosyltransferase UGT-1A3.; and phase III: ATP-binding cassette ABC-B1. Genes whose expression was induced by 
Mencarelli A. et al. Rifaximin regulates intestinal PXR

exposure of either primary epithelial cells and human colon biopsies to rifaximin is shown in orange.

\begin{tabular}{|c|c|c|c|c|}
\hline Gene & $\begin{array}{l}\text { Effect of } \\
\text { rifaximin in } \\
\text { naïve cells }\end{array}$ & $\begin{array}{l}\text { Effect of TNFa } \\
\text { in naïve cells }\end{array}$ & $\begin{array}{c}\text { Effects of } \\
\text { Rifaximin } \\
\text { mediated by PXR } \\
\text { (abrogated by } \\
\text { anti-PXR siRNA) }\end{array}$ & $\begin{array}{c}\text { Effect of rifaximin } \\
\text { in IBD biopsies }\end{array}$ \\
\hline Phase I & & & & 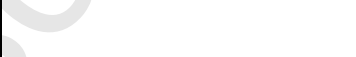 \\
\hline CYP-3A4 & Increased & Decreased & YES & No effect \\
\hline СYР-2C9 & Increased & Decreased & NO & Increased \\
\hline CYP-3A7 & Increased & Decreased & YES & Increased \\
\hline CES-2 & No effect & No effect & NO & No effect \\
\hline GXP-1 & No effect & No effect & $\mathrm{NO}$ & No effect \\
\hline Phase II & & & 3 & \\
\hline GST-A1 & Increased & Decreased & YES & No effect \\
\hline GST-M4 & No effect & Decreased & NO & No effect \\
\hline GST-T1 & No effect & No effect & YES & No effect \\
\hline SULT-1A1 & Increased & Decreased & YES & Increased \\
\hline SULT-1A3 & Increased & Decreased & YES & No effect \\
\hline SULT-2A1 & Increased & Decreased & YES & Increased \\
\hline UGT-1A3 & Increased & Decreased & YES & Increased \\
\hline Phase III & & & & \\
\hline ABC-B1 & Increased & Decreased & YES & Increased \\
\hline ABC-C2 & Increased & Decreased & YES & No effect \\
\hline ABC-C3 & Increased & Decreased & $\mathrm{NO}$ & Increased \\
\hline PXR & Increased & Decreased & & No effect \\
\hline
\end{tabular}




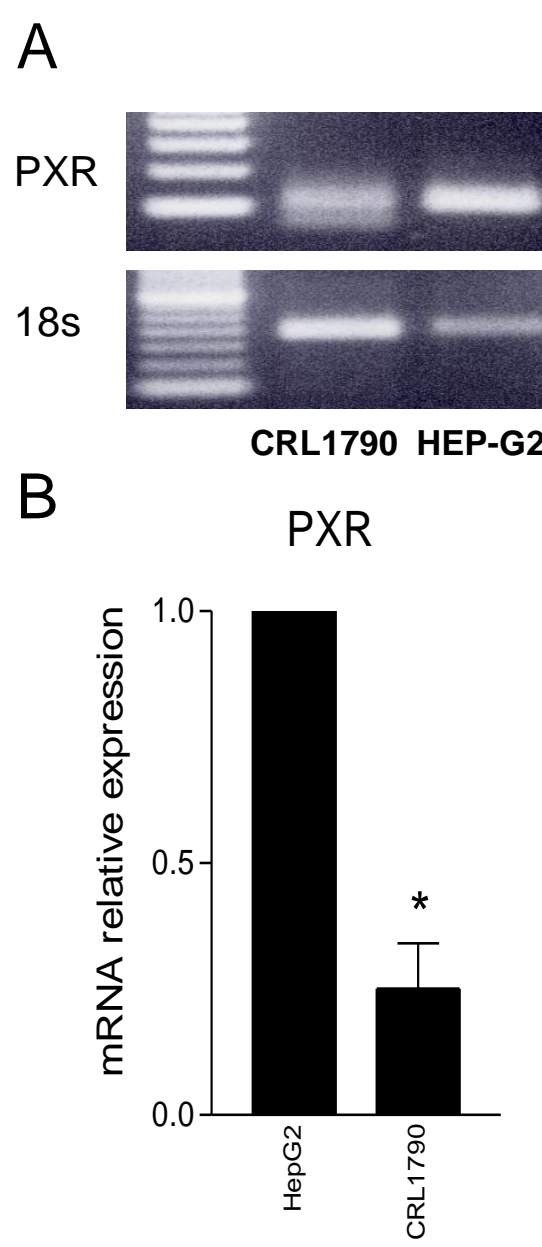

Figure 1 
- Naive Rifaximin $50 \mu \mathrm{M}$
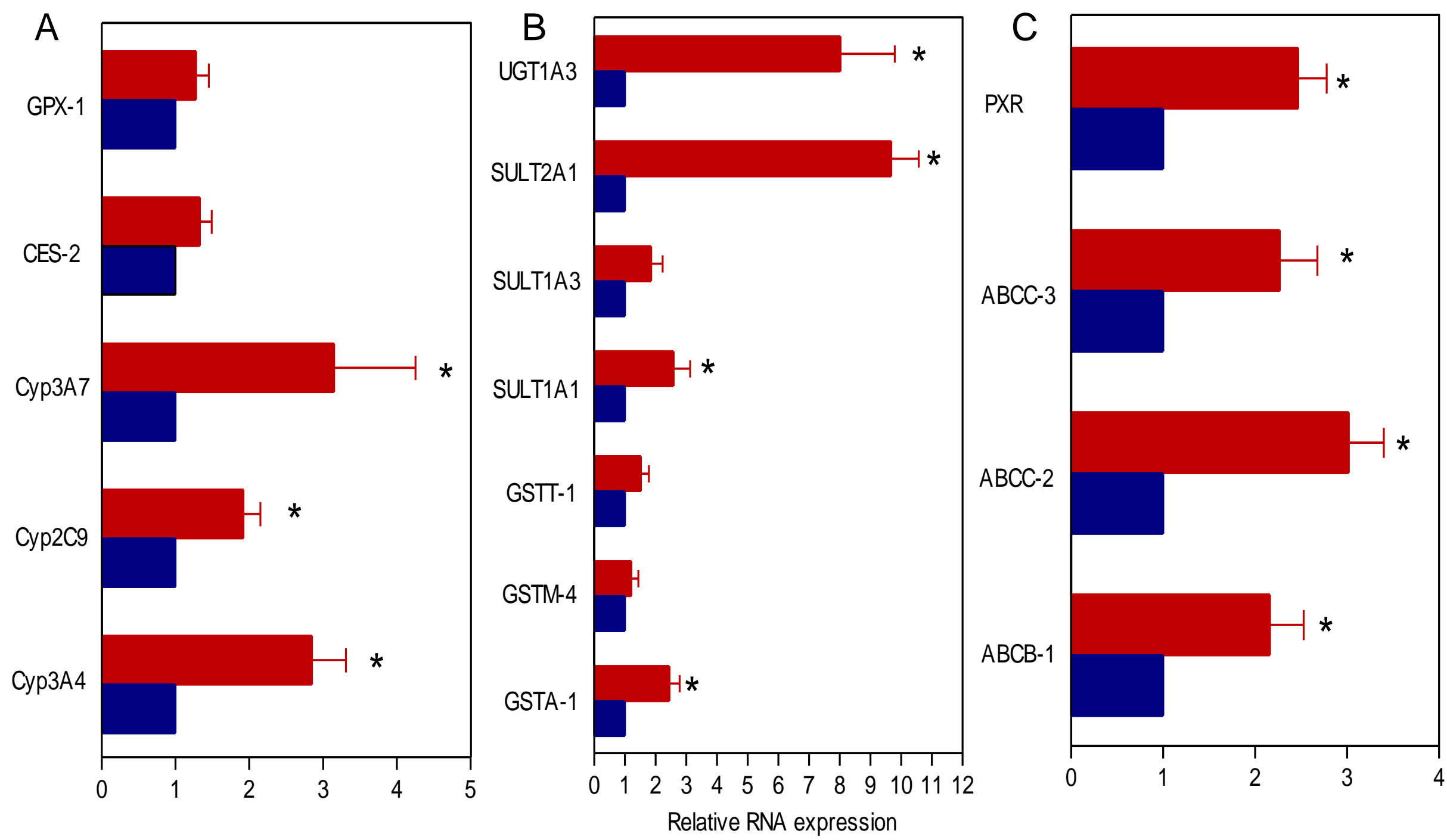

Figure 2 
Naive $\quad$ TNFa $\quad$ TNF $\alpha+$ rifaximin

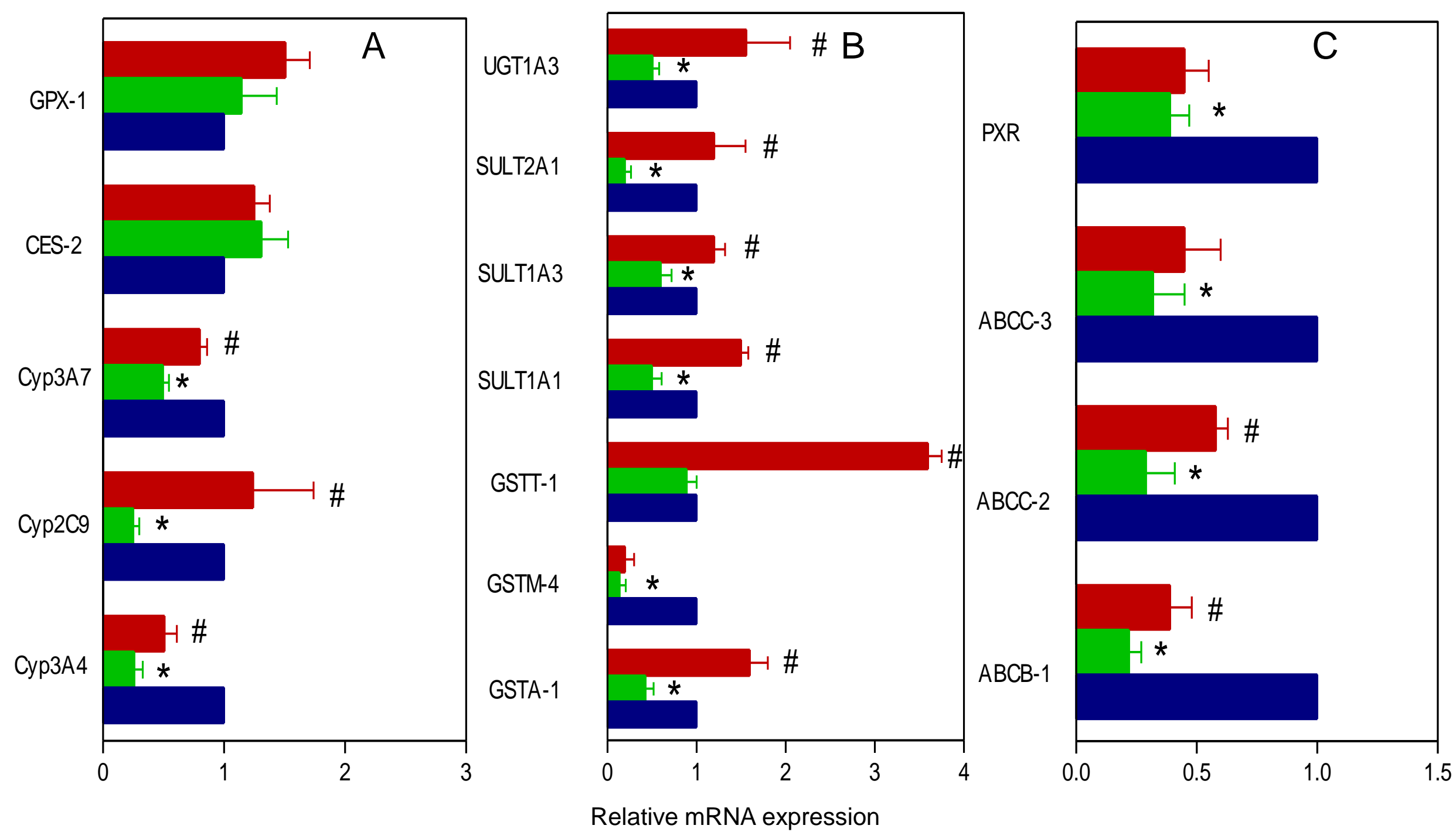

Figure 3 

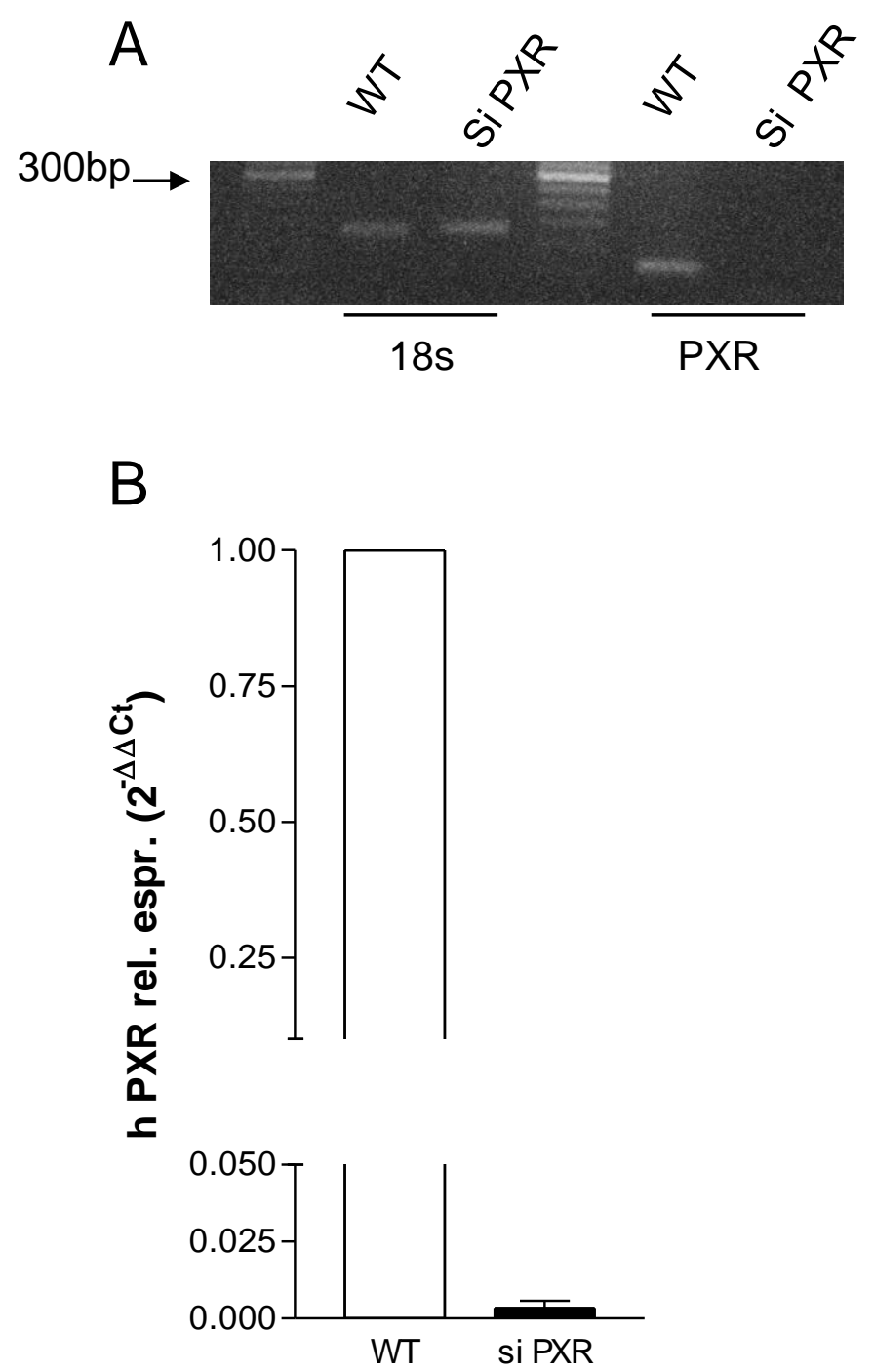

Figure 4 
- WT cells + TNFa

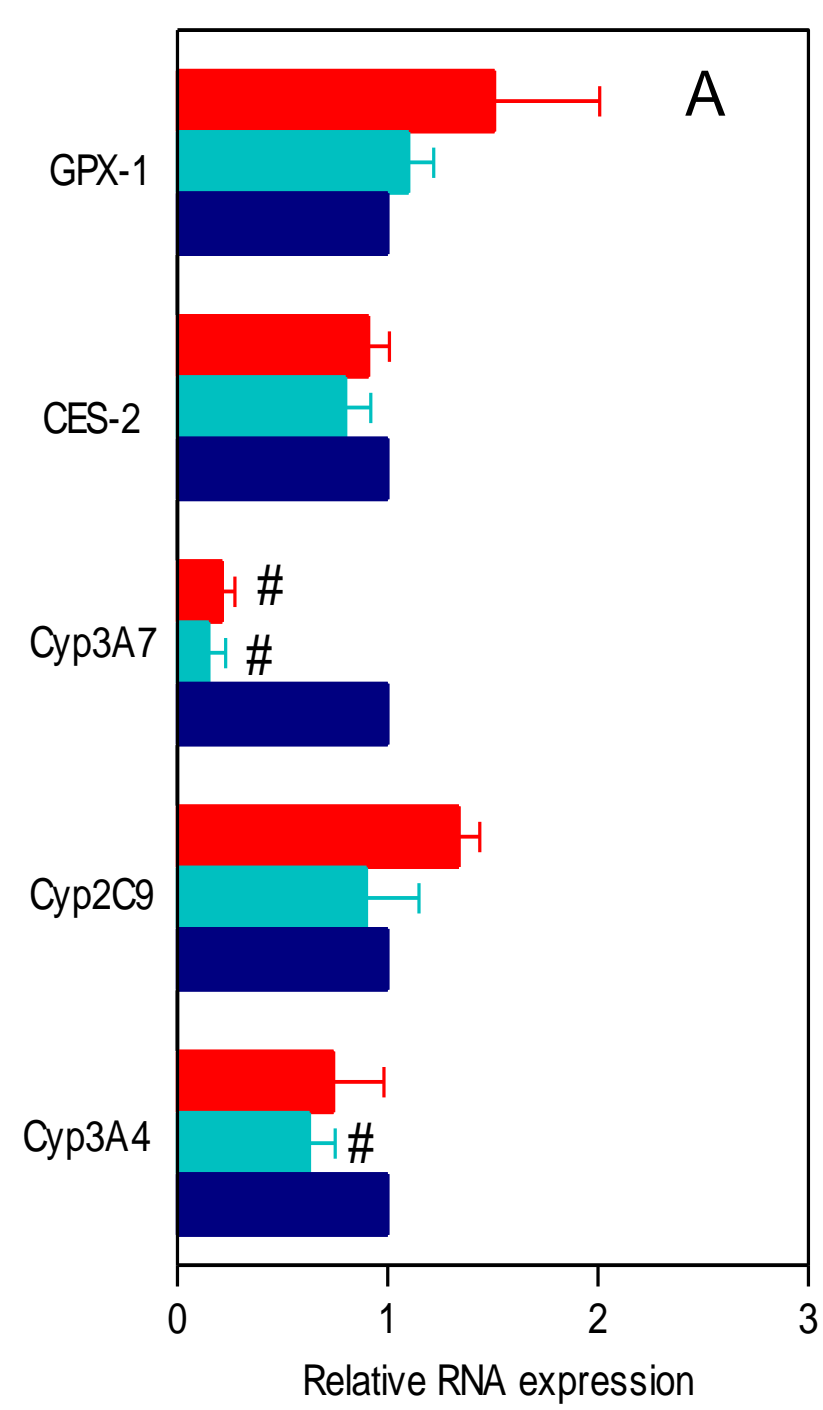

$\square \operatorname{siPXR}+\mathrm{TNF} \alpha$

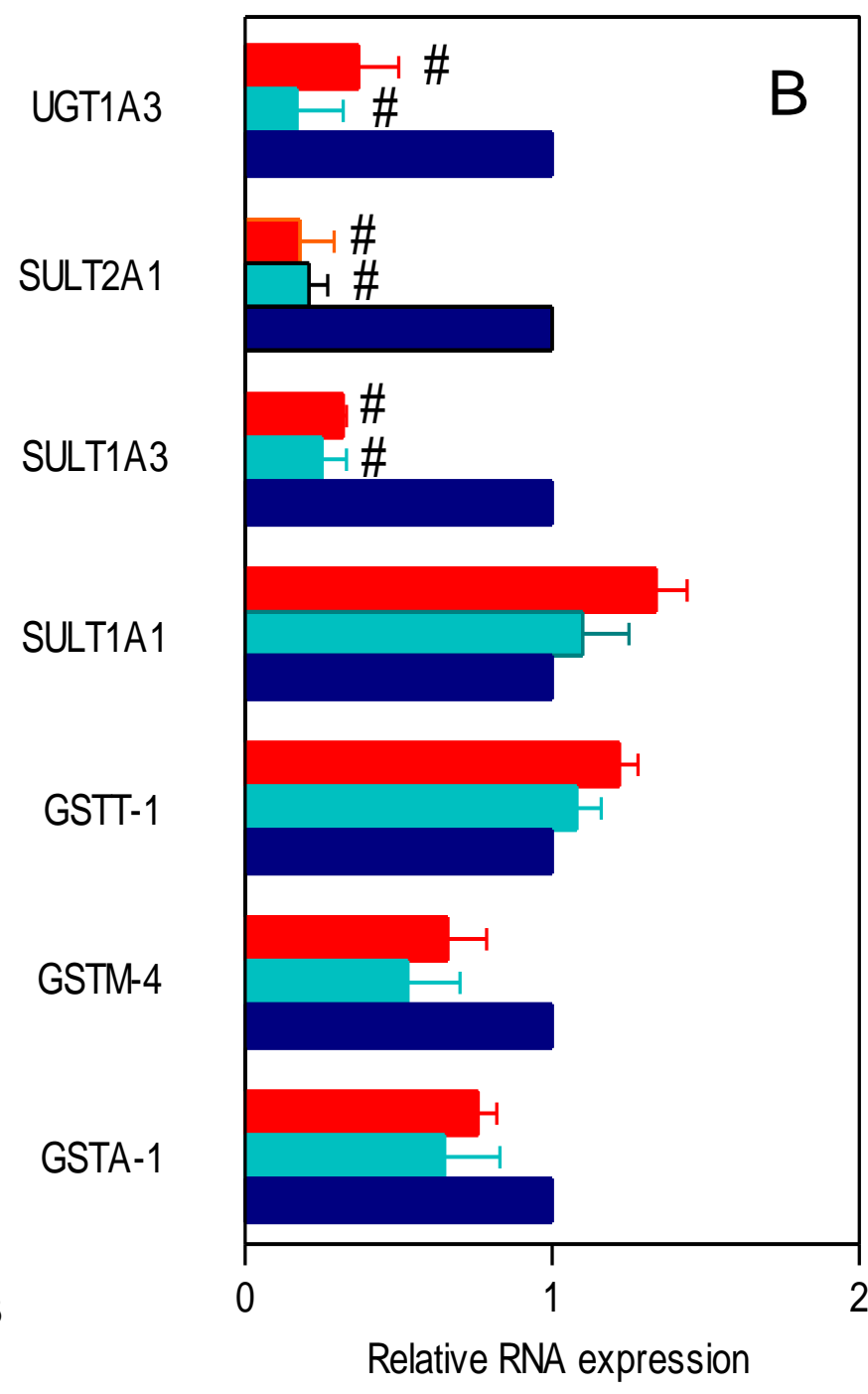

\section{siPXR +TNFa + Rifaximin}

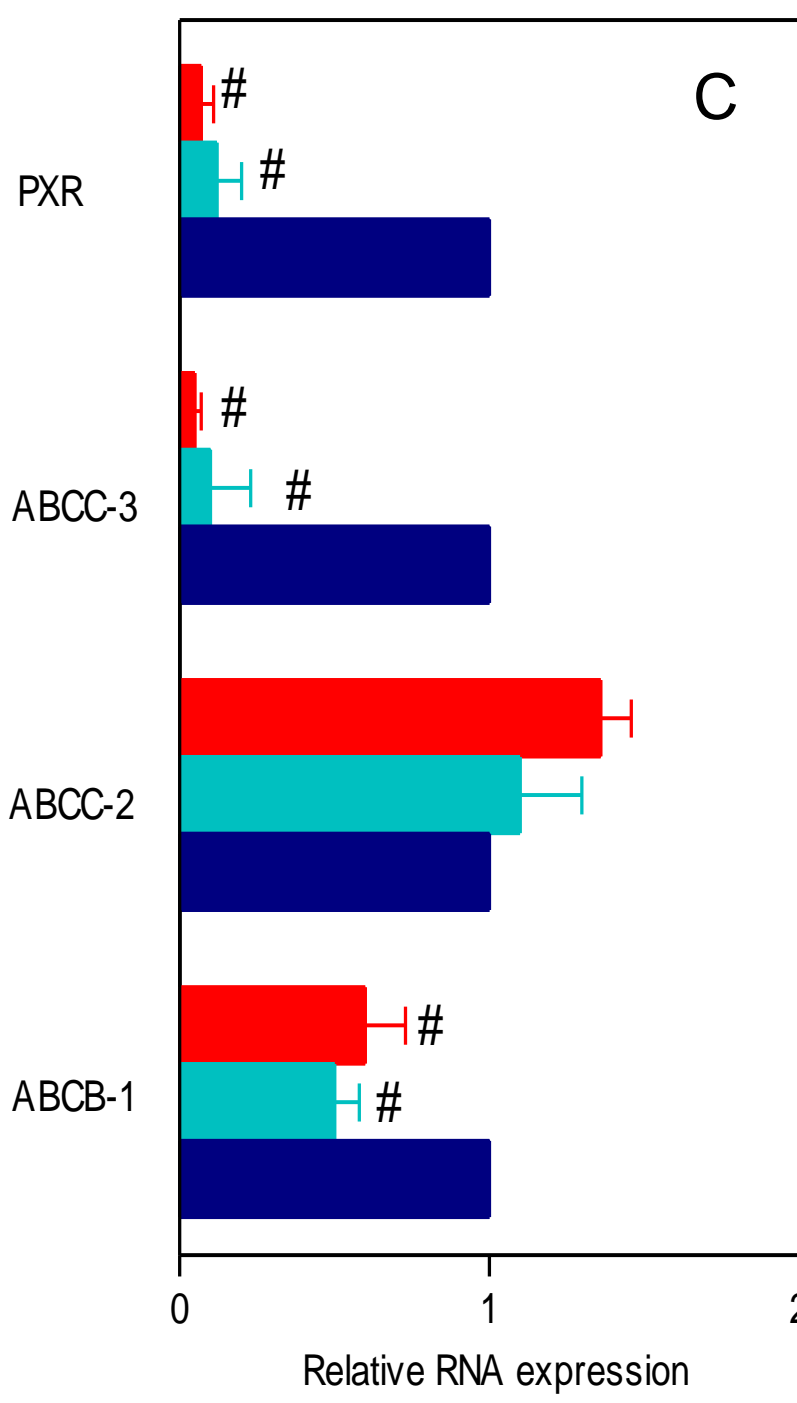

Figure 5 
口 Naive $\square$ Rifaximin $100 \mu \mathrm{M}$
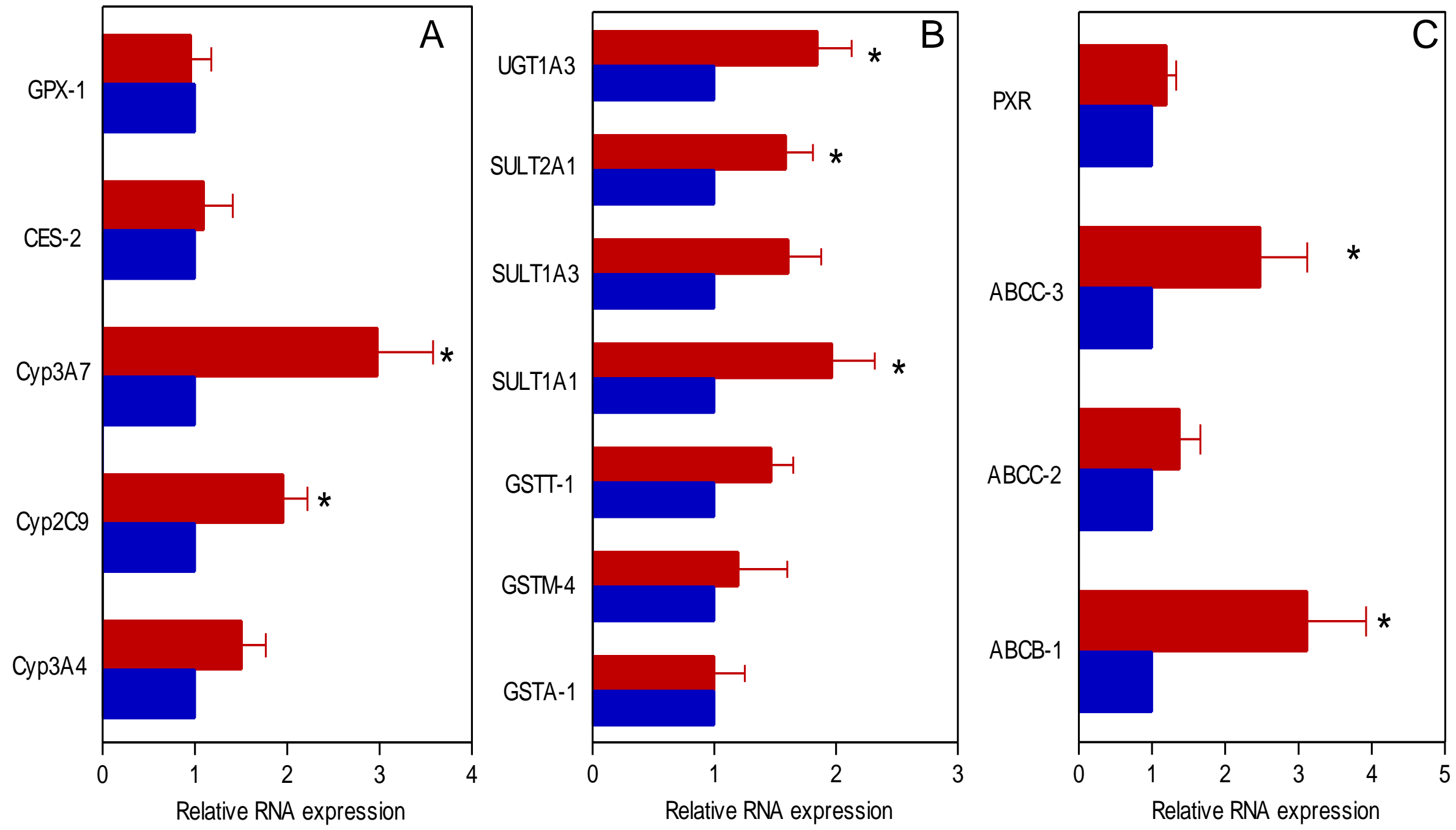

Figure 6 
Rifaximin , a non absorbable antibiotic, is a PXR ligand and increases the expression of genes involved in the metabolism and excretion of xenobiotics and antagonized the effects of TNFa in human intetsinal epithelial cells and colon biopsies
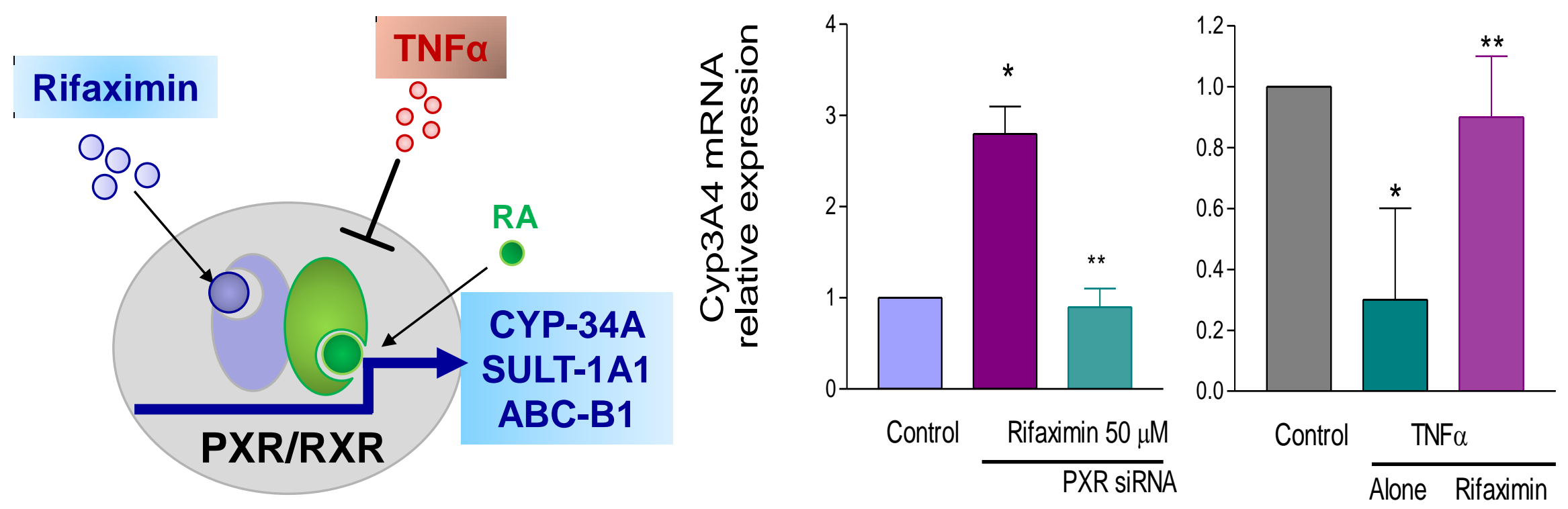

\section{Intestinal epithelial cell}

Abbreviation: RA: retinoic acid; CYP-3A4: Cytochrome P450-3A4; SULTA1: sulfotransferase-1A1; ABC-B1: ATP binding cassette superfamily,subfamily $B$,member 1; PXR siRNA: small interfering RNA for PXR (pregnane X receptor). 